\title{
Corporate Social Responsibility and Labour Standards: Bridging Business Management and Employment Relations Perspectives
}

\author{
Gregory Jackson, Virginia Doellgast \\ and Lucio Baccaro
}

\section{Article by an MPIfG researcher}

Gregory Jackson, Virginia Doellgast, Lucio Baccaro: Corporate Social Responsibility and Labour Standards: Bridging Business Management and Employment Relations Perspectives. In: British Journal of Industrial Relations 56(1), 3-13 (2018). Wiley-Blackwell The original publication is available at the publisher's web site: https://doi.org/10.1111/bjir.12298

\section{Introduction}

The special symposium of the British Journal of Industrial Relations (BJIR) is dedicated to corporate social responsibility (CSR) and labour standards. CSR can be defined as corporate actions oriented towards the welfare of stakeholders and driven by instrumental, relational or ethical concerns (Aguilera et al. 2007). Viewed as a relational concept, the study of CSR is concerned with both the claims about responsibility that corporations make about themselves, as well as the demands articulated by stakeholders in relation to social, environmental and other responsibilities. Thus, we advocate an empirical approach to CSR that treats questions of responsibility as political ones, negotiated among business, stakeholders and the wider society. Such a definition also encompasses corporate irresponsibility, since stakeholders may view the actions of a corporation as unethical and thus the issue of CSR as a contested terrain (Okoye 2009).

CSR has sparked substantial controversy. Many business management scholars have embraced CSR as a more human approach to capitalism that takes on board the notion that social legitimacy is a central prerequisite for profitability and that environmental sustainability is critical for the long-term economic development. Meanwhile, a minority of scholars across different social sciences remain more critical. CSR may be seen as a tool of symbolic management or even an active form of corporate 'greenwashing' aimed to distract stakeholders from unsustainable or unethical activities (e.g. Marquis 
et al. 2015). At its worst, CSR may be associated with state deregulation and the rise of neoliberalism, which have led to the erosion of social standards globally (e.g. Kinderman 2012).

Just as trade unions themselves have been 'reluctant stakeholders' in the CSR debate (Preuss 2008), employee relations (ER) scholars have been slow to engage with CSR scholarship. Similarly, the management literature on CSR rarely integrates perspectives and insights from ER, which focuses greater attention to the role of employees and wider political dynamics of governance (see also discussion in Tapia et al. 2015). Despite the plurality of theories (Taneja et al. 2011), insufficient integration has taken place to do justice to both the promise and limitations of CSR.

The BJIR Symposium hopes to build bridges between these perspectives, and deepen understanding of why CSR policies emerge, how they function and what concrete results they achieve.

\section{The business case for CSR: Key assumptions and limitations}

Much existing literature in management has been concerned with the so-called business case for CSR (Porter and Kramer 2011), which stresses the potential positive sum relationship between ethical business and financial returns. This idea has become conventional wisdom within public debates around CSR and is strongly institutionalized in the field of socially responsible investing and international standards around non-financial reporting and increasing the transparency of economic, social and governance-related activities (for Germany, see Lohmeyer 2017).

The CSR literature on the business case is built around several interrelated assumptions. First, CSR is assumed to create tangible benefits for stakeholders, which in turn give benefits back to the firms such as better corporate reputation and improved financial performance (Brower and Mahajan 2013; Tang et al. 2012). Employment policies such as worker safety, social benefits and internal communication improve worker productivity due to less employee turnover and protection of firm-specific skills; or better use of human capital. Other benefits relate to improved reputation also among customers. However, most of the literature on CSR includes employment practices as one part of a larger CSR bundle; and does not attempt to measure the impact on employment outcomes directly. It is thus perhaps unsurprising that the business management scholars have yet to find clear supportive evidence linking CSR to financial performance - these relationships apply only in certain market niches (Vogel 2006) or face diminishing returns due to associated costs (Barnett and Salomon 2006). The business case for CSR also relies on a converse argument - namely, that stakeholders are able not only to reward 'good' behaviours, but also sanction 'bad' behaviour. Recent evidence, however, demonstrates this link to be very weak (see detailed discussion in Jackson et al. 2014). Financial markets have only a short memory regarding scandals, just as major brands such as Apple maintain positive reputations 
with consumers despite controversies surrounding labour conditions or tax avoidance (Hoi et al. 2013). Indeed, firms adopting more CSR also engage in more irresponsible activities, not less (Kotchen and Moon 2012), particularly in the USA, UK and Germany (Jackson and Bartosch 2016).

Second, the CSR literature is largely managerialist in orientation. CSR is framed as a strategic choice by managers, which is voluntary and shaped by instrumental motivations or in some cases also their personal characteristics. Even the EU policy documents defined CSR in 2001 as 'a concept whereby companies integrate social and environmental concerns in their business operations... on a voluntary basis' [emphasis added]. The business case for CSR is also argued to be stronger where salience of stakeholders is higher, reflecting their legitimacy, urgency and power of stakeholders vis-à-vis the firm (Mitchell et al. 1997). But analyses of how and why particular stakeholders become salient remain underdeveloped (Perrini et al. 2011). Some important contributions do examine the impact of non-governmental organizations (NGOs) (Doh and Guay 2006; Seitanidi and Crane 2009) or the impact of institutional investors' use of CSR-related screening (Barnea and Rubin 2010) on CSR adoption.

It is striking that employees and trade unions play almost no role in the business literature on CSR. While workers are often the addressees of CSR activities, their influence on shaping CSR and how CSR influences their well-being are rarely studied. ${ }^{1}$ Management research has given insufficient attention to the tensions related to the plurality of actors that negotiate and implement CSR within organizations (Locke 2013), and thereby neglects the symbolic and contestable nature of CSR itself.

Third, the business literature has only begun to address the institutional embeddedness of CSR. The macro-level political dynamics of CSR as an emerging field of 'private regulation' (Brammer et al. 2012) and its relationship to new forms of transnational soft law (Baccaro and Mele 2012). Neoinstitutional scholars have shown that CSR is a global norm undergoing transnational diffusion and various local adaptation (e.g. Lim and Tsutsui 2012). Meanwhile, CSR is argued to build upon institutionalized forms of stakeholders rights, and therefore develops to a greater extent in the presence of more 'co-ordinated' forms of capitalism (Campbell 2007). Matten and Moon (2008) interpreted this as a shift from being largely 'implicit' in these contexts to being more 'explicit' and transparent to the market. Other studies found evidence for the opposite, namely, that CSR develops as a substitute for state regulation, with more extensive adoption in liberal market-oriented contexts (Jackson and Apostolakou 2010). Along similar lines, multinational firms adopt CSR in host countries with weak institutions or failed states (Rathert 2016).

In sum, business scholars have developed a rich understanding of CSR practices and tools for measuring these practices at the level of the firm, while examining some conditions under which a 'business case' may exist for CSR. At the same time, this perspective has clear limitations in understanding the contingencies that make CSR more or less effective. Addressing these limits 
would entail shifting attention: from financial performance to stakeholder welfare, from management strategy to how stakeholders negotiate the content and implementation of CSR and from the firm-level to the wider political economy.

\section{Towards an ER perspective on CSR?}

While ER scholarship encompasses heterogeneous traditions, we argue that ER scholars have paradigmatic strengths that offer several important contrasts with the CSR literature.

First, in studying CSR, ER scholars have focused attention on outcomes related to employee welfare, for example, by showing the ambiguous impact of CSR related to labour standards. Pioneering work on the case of Nike has shown compliance to remain surprisingly low, and fraught with challenges related to implementation (Locke 2013). Other research shows variation in compliance with labour standards, linked to factors such as worker awareness and human capital (Smyth et al. 2013). Based on ethnographic research, Costas and Kärreman (2013) found that employees often participated in or demanded CSR activities as a way to express their identities and ethical conscience to the organization, but such practices also facilitated greater social control and ethical distancing to morally questionable activities within the firm.

Second, ER scholars have adopted a more pluralistic view of the firm and its stakeholders. A key finding from ER research concerns the positive role played by trade unions in the effective implementation of CSR. For example, Oka (2016) shows that factories in Cambodia's garment export sector with union presence were more likely to comply with standards on wages, working hours and employee leave. Unions in the Indonesian footwear industry have also been able to use CSR to strengthen their foothold, but also to leverage stronger implementation of labour-relevant CSR standards (Bartley and Egels-Zandén 2016). Union democracy and collective representation have also been found to strengthen the input legitimacy of CSR (Harvey et al. 2017; Sobczak and Havard 2015).

One growing area of research is on international forms of collective bargaining, including International Framework Agreements (IFAs). While much research shows difficulties enforcing IFAs at the local level (Helfen and Sydow 2013), they can also serve as resources for unions in local bargaining (Dehnen 2013). Mustchin and Lucio (2017) show that UK trade unions referenced or engaged with these agreements to strengthen their influence on multinational corporations; with best outcomes where institutions supported co-ordination across different levels of the firm (see also Fichter et al. 2011). The structure of global value chains (Riisgaard and Hammer 2011) and the intersection of union and employer strategies (Williams et al. 2015) have also been found to affect labour's leverage and influence in both IFAs and multistakeholder codes of conduct. 
Third, the role of CSR as a political ideology has been examined by ER scholars. Historically, the emergence of CSR in the USA was closely linked with paternalistic and anti-union positions by employers, and often a strategy to defeat organized labour (Kaplan 2015; Marens 2012). This pattern of corporate dominance and avoidance of meaningful stakeholder participation carries onto this day, in cases such as Walmart (Elder and Dauvergne 2015). Nonetheless, ER scholars have also demonstrated the role of workers and organized labour in creating complementary relationships between CSR and state regulations (Amengual 2010). In their case study of a global electronics firm, Locke et al. (2013) show the very contingent relations between CSR, state regulation and organized labour, which may exhibit both complementary and substitutive relationships with one another depending on the political context.

Based on this very selective review of ER scholarship, we submit that CSR scholars could benefit from concepts and research approaches found in ER scholarship. Often grounded in qualitative or even ethnographic work, ER research has highlighted the central role of employees and workrelated outcomes, examined the critical role of (employee) stakeholders in the negotiation and implementation of CSR policies and explored the linkages between firms and their regulatory and political environments. Equally, the rich findings suggest that ER scholars have reason to take CSR more seriously, both from a critical perspective and as an important tool to improve working conditions globally. CSR is an important platform for union engagement with civil society actors and new social movements, and hence likely to be important for union revitalization.

\section{The Symposium}

A first theme of the Symposium concerns international labour standards and global supply chains. Global firms face heterogeneous labour regulations across countries, as well as public pressure regarding their role as lead firm in long chains of buyer-supplier relations. The Rana Plaza disaster in 2013 quickly became emblematic for all the severe abuses of workers in this context. Juliane Reinecke and Jimmy Donaghey (this issue) examine the divergent responses of global firms to this crisis manifest in the 'Accord for Fire and Building Safety in Bangladesh' (Accord) versus the 'Alliance for Bangladesh Worker Safety' (Alliance). Drawing on interviews and field research in Bangladesh, they argue that these two initiatives are grounded in logics of CSR versus industrial democracy.

The Accord reflects a pluralist logic of industrial democracy, which conceives of legitimacy and accountability in terms of democratic participation, worker rights and credible commitments. This was reflected in its grounding in legally binding agreements involving global union federations, utilizing a negotiated set of rights. This model was rejected by 29 US brands led by Gap and WalMart, who then launched the Alliance, which followed CSR logic based on a unitarist concept of the firm and a 
flexible and voluntarist approach to accountability. The Alliance relied on brand reputation, as well as voluntary and unilateral actions of leading firms. These two approaches interacted, however, to shape outcomes. Engagement with CSR in the Accord case helped speed responses, leveraging the power of brands within the supply chain, even in the absence of direct state support and employer opposition. Meanwhile, the Accord helped raised public scrutiny of the Alliance, pushing them towards higher standards than would have existed.

In global supply chains, sustainability standards, such as Fairtrade certification, are one form of voluntary regulation that targets socially conscious consumers. Here, CSR is intended to improve working conditions, but also combat poverty within communities of the global South particularly those dependent on agriculture or other commodities subject to large price and demand fluctuations. Maja Tampe (this issue) asks under what conditions these sustainability standards succeed or fail, based on a comparison of two similar certified groups of Ecuadorian cocoa farmers organized in certified rural enterprises. Her findings show more favourable outcomes in the case study enterprise that developed diversified, learningoriented relationships with buyers; and that also passed these benefits on to its member farmers.

Tampe's findings contribute to the literature on Global Production Networks (GPNs) through examining how supplier and labour agency can shape the process of supplier upgrading. She agrees with the GPN literature (e.g. Gereffi and Lee 2014) that a close buyer-supplier relationship oriented to learning drives upgrading - which, in turn is a key condition for sustainability standards to actually improve local livelihoods in rural communities. However, she shows that this relationship is not sufficient: instead, ties have to be diversified across multiple buyers; and mechanisms have to be in place within the enterprise itself to experiment with and adapt taught practices. Thus, access to 'premium markets' was not enough on its own to improve local labour conditions: the farmer group's capacity and willingness to share benefits with members were both crucial for outcomes.

CSR initiatives more generally have important impacts on worker power and the role of organized labour in global value chains. Marc Anner (this issue) examines the apparel industry in Vietnam to show the prospect and limitations of worker power in global supply chains. He uses an innovative approach to document the 'sourcing squeeze' whereby lead firms pressure their suppliers to produce for low prices and with accelerating turn-around times, showing a 20 per cent decline in price paid per square metre of apparel exports from Vietnam to the USA between 2005 and 2016. The market power of lead firms pressures management in the host country to keep wages low and working hours long.

Using extensive evidence based on field observation, survey data and interviews, Anner shows that the realities of fast production often undermine the effective use of worker voice, despite the existence of workermanagement participation committees and union representation within the CSR framework of the Better Work initiative. While the sourcing squeeze 
remains a strong constraint on worker voice, Anner shows that worker power comes from short, local wildcat strikes. Shorter lead times mean that supplier firms remain very vulnerable to disruptions in production, which effectively elicit short-term responses from employers to make small changes in working conditions or wages.

A second theme of the Symposium relates to the impact of CSR on workplace diversity. In their study, Takao Kato and Naomi Kodama (this issue) investigate the relationship between CSR practices and gender diversity at work in Japan. Here, Japanese firms have remained seriously behind many OECD countries, a fact particularly striking given the renown of Japanese firms for long-term employment and co-operative industrial relations. The global discourse on CSR, however, has helped put the issue of gender equality more strongly onto the agenda of firms, offering new ways to frame old issues through stressing the positive 'business case' of diversity.

Using firm-level panel data, Kato and Kodama show that increases in CSR activities do positively impact gender diversity through encouraging adoption of human resource practices aiming at improved work-life balance. However, the evidence also suggests that CSR adoption has an additional direct impact, most likely as a signal that the company is committed to gender equality. Finally, the authors show an important role for stakeholder salience, as in the previous literature on CSR, but make important links here to industrial relations factors. They show that the impact of CSR is stronger in firms with a strong lifetime employment norm, which is a central element of firm-centred industrial relations, often underpinned by enterprise unions and extensive employee participation. While it would be premature to generalize these findings beyond Japan, the results do suggest potential complementarities between CSR and other forms of worker voice.

A final theme of the Symposium relates to the political dynamics of CSR and its relation to public regulation and governance. Brian Burgoon and Luc Fransen (this issue) examine the potential tensions between public and private regulatory activity on labour and social standards. They use public opinion data from $27 \mathrm{EU}$ countries to explore the links between the extent of CSR activities in different countries and the degree of public support for redistribution and foreign aid policies. Findings show that CSR activities may indeed crowd out public support for domestic redistribution of income, largely through weakening the links between individual characteristics and public support. Their study has interesting implications for the wider political economy understanding of private governance by demonstrating a clear mechanism for the substitutional hypothesis, namely, that private governance activities may actively push countries towards reduction of public activities. However, no such effect is evident regarding support for foreign aid. In this case, private governance activities may be more complementary to public ones. While the authors are very cautious about generalizing across different areas of public policy, their results suggest an important research agenda in understanding these political dynamics, both in terms of political power of interest groups but also public opinion. 
Continuing the theme of public regulation of CSR, Jette Knudsen (this issue) asks how and why government CSR initiatives - targeting apparel industry labour standards and tax transparency in extractive industries took different forms across the UK and the USA in the late 2000s to early 2010s. The UK government encouraged multi-stakeholder initiatives in both industries, which Knudsen argues can be traced to the UK's more flexible, informal legal system and parliamentary system of government. In contrast, the US government has favoured mandatory regulation in extractives and apparel. Knudsen attributes this to US traditions of adversarial legalism, grounded within a more politically fragmented decision-making system that relies more heavily on judicial action to implement public policy. Notably, these initiatives were implemented under the Labour Party in the UK and Democratic Party in the USA. While government policies on CSR are converging worldwide, other developments suggest these improvements are fragile, threatened by legislative initiatives by the Trump Administration and Republican-controlled Congress and the UK's pending 'Brexit' from the EU.

\section{Outlook}

Debates on CSR increasingly cross disciplines, intersecting also with questions and concerns of ER research. This Symposium highlights several ways in which CSR may have positive impacts on employees, and may complement traditional institutions of worker voice. CSR scholars have long realized that when state regulation may be absent or weak (even where desirable), it is important to understand what factors may support corporate managers' engagement with social issues. They also study the role of other actors, such as NGOs and investors, which are often outside the purview of ER scholarship. The dynamics of these stakeholder interactions and their use of private governance mechanisms around CSR may have important implications for understanding union revitalization, transnational labour solidarity and the influence of global value chains or financialization on workers - grand challenges raised in the 50th anniversary issue of BJIR (Jackson et al. 2013).

While the instrumental focus on a 'business case' may help persuade managers that pursuing CSR is in the interest of their firms, this perspective also has important limits. We hope that this Symposium also raises awareness of the strengths of ER research and its potential contribution to the business management literature on CSR. ER scholars have very deep knowledge of one key corporate stakeholder: the employee. Their research offers well-developed conceptual tools to understand governance as a politically negotiated process, and examine the interactions between voluntary and mandatory, private and public and other governance dichotomies. We also believe it is important to acknowledge the research sensibility of ER scholarship - which has drawn on ethnographic and other qualitative research traditions. ER researchers are best placed to go into the workplace to look very concretely at the real situation 
of those people allegedly being addressed by CSR measures, allowing them to confront claims about corporate responsibility with academic fact finding.

\section{Note}

1. We are indebted for this point to Divya Jyoti, 'Making Room for Factory Workers in Corporate Social Responsibility', at Stanford PACS PhD Workshop on Alternative Organizational Forms in the Economy, Hertie School of Governance Berlin, 21-22 June 2017.

\section{References}

Aguilera, R., Rupp, D., Williams, C. A. and Ganapathi, J. (2007). 'Putting the S back in CSR: a multi-level theory of social change in organizations'. Academy of Management Review, 32 (2): 836-63.

Amengual, M. (2010). 'Complementary labor regulation: the uncoordinated combination of state and private regulators in the Dominican Republic'. World Development, 38 (3): 405-14.

Baccaro, L. and Mele, V. (2012). 'Pathology of path dependency? The ILO and the challenge of new governance'. Industrial \& Labor Relations Review, 65 (2): 195-224.

Barnea, A. and Rubin, A. (2010). 'Corporate social responsibility as a conflict between shareholders'. Journal of Business Ethics, 97 (1): 71-86.

Barnett, M. L. and Salomon, R. M. (2006). 'Beyond dichotomy: the curvilinear relationship between social responsibility and financial performance'. Strategic Management Journal, 27 (11): 1101-22.

Bartley, T. and Egels-Zandén, N. (2016). 'Beyond decoupling: unions and the leveraging of corporate social responsibility in Indonesia'. Socio-Economic Review, 14 (2): 231-55.

Brammer, S., Jackson, G. and Matten, D. (2012). 'Corporate social responsibility and institutional theory: new perspectives on private governance'. Socio-Economic Review, 10 (1): 3-28.

Brower, J. and Mahajan, V. (2013). 'Driven to be good: a stakeholder theory perspective on the drivers of corporate social performance'. Journal of Business Ethics, 117 (2): 313-31.

Campbell, J. L. (2007). 'Why would corporations behave in socially responsible ways? An institutional theory of corporate social responsibility'. Academy of Management Review, 32 (3): 946-67.

Costas, J. and Kärreman, D. (2013). 'Conscience as control - managing employees through CSR'. Organization, 20 (3): 394-415.

Dehnen, V. (2013). 'Transnational alliances for negotiating international framework agreements: power relations and bargaining processes between Global Union Federations and European Works Councils'. British Journal of Industrial Relations, 51 (3): 577-600.

Doh, J. P. and Guay, T. R. (2006). 'Corporate social responsibility, public policy, and NGO activism in Europe and the United States: an institutional-stakeholder perspective'. Journal of Management Studies, 43 (1): 47-73.

Elder, S. D. and Dauvergne, P. (2015). 'Farming for Walmart: the politics of corporate control and responsibility in the global South'. Journal of Peasant Studies, 42 (5): $1029-46$. 
Fichter, M., Helfen, M. and Sydow, J. (2011). 'Employment relations in global production networks: initiating transfer of practices via union involvement'. Human Relations, 64 (4): 599-622.

Harvey, G., Hodder, A. and Brammer, S. (2017). 'Trade union participation in CSR deliberation: an evaluation'. Industrial Relations Journal, 48 (1): 42-55.

Helfen, M. and Sydow, J. (2013). 'Negotiating as institutional work: the case of labour standards and international framework agreements'. Organization Studies, 34 (8): 1073-98.

Hoi, C. K., Wu, Q. and Zhang, H. (2013). 'Is corporate social responsibility (CSR) associated with tax avoidance? Evidence from irresponsible CSR activities'. Accounting Review, 88 (6): 2025-59.

Jackson, G. and Apostolakou, A. (2010). 'Corporate social responsibility in Western Europe: an institutional mirror or substitute?' Journal of Business Ethics, 94 (3): 371-94.

- and Bartosch, J. (2016). Corporate Responsibility in Different Varieties of Capitalism: Exploring the Role of National Institutions. Gutersloh: Bertelsmann Foundation.

—_, Brammer, S., Karpoff, J. M., Lange, D., Zavyalova, A., Harrington, B., Partnoy, F., King, B. G, Deephouse, D. L., Jackson, G., Brammer, S., Karpoff, J. M., Lange, D., Zavyalova, A., Harrington, B., Partnoy, F., King, B. G and Deephouse, D. L. (2014). 'Grey areas: irresponsible corporations and reputational dynamics'. SocioEconomic Review, 12 (1): 153-218.

— Kuruvilla, S. and Frege, C. (2013). 'Across boundaries: the global challenges facing workers and employment research'. British Journal of Industrial Relations, 51 (3): 425-39.

Kaplan, R. (2015). 'Who has been regulating whom, business or society? The mid20th-century institutionalization of "corporate responsibility" in the USA'. SocioEconomic Review, 13 (1): 125-55.

Kinderman, D. (2012). "Free us up so we can be responsible!" The co-evolution of corporate social responsibility and neo-liberalism in the UK, 1977-2010'. SocioEconomic Review, 10 (1): 29-57.

Kotchen, M. and Moon, J. J. (2012). 'Corporate social responsibility for irresponsibility'. B E Journal of Economic Analysis \& Policy, 12(1), article 55.

Lim, A. and Tsutsui, K. (2012). 'Globalization and commitment in corporate social responsibility: cross-national analyses of institutional and political-economy effects'. American Sociological Review, 77 (1): 69-98.

Locke, R. M. (2013). The Promise and Limits of Private Power: Promoting Labor Standards in a Global Economy. Cambridge: Cambridge University Press.

— Rissing, B. A. and Pal, T. (2013). 'Complements or substitutes? Private codes, state regulation and the enforcement of labour standards in global supply chains'. British Journal of Industrial Relations, 51 (3): 519-52.

Lohmeyer, N. (2017). Instrumentalisierte Verantwortung?: Entstehung und Motive des 'Business Case for CSR' im deutschen Diskurs unternehmerischer Verantwortung. Bielefeld: Transcript Verlag.

Marens, R. (2012). 'Generous in victory? American managerial autonomy, labour relations and the invention of Corporate Social Responsibility'. Socio-Economic Review, 10 (1): 59-84.

Marquis, C., Toffel, M. W and Zhou, Y. (2015). 'Scrutiny, norms, and selective disclosure: a global study of greenwashing'. Harvard Business School Organizational Behavior Unit Working Paper, 11-115. 
Matten, D. and Moon, J. (2008). "Implicit" and "explicit" CSR: a conceptual framework for a comparative understanding of corporate social responsibility'. Academy of Management Review, 33 (2): 404-24.

Mitchell, R. K., Agle, B. R. and Wood, D. J. (1997). 'Toward a theory of stakeholder identification and salience: defining the principle of who and what really counts'. Academy of Management Review, 22 (4): 853-86.

Mustchin, S. and Lucio, M. M. (2017). 'Transnational collective agreements and the development of new spaces for union action: the formal and informal uses of international and European framework agreements in the UK'. British Journal of Industrial Relations, 55 (3): 577-601.

Oka, C. (2016). 'Improving working conditions in garment supply chains: the role of unions in Cambodia'. British Journal of Industrial Relations, 54 (3): 647-72.

Okoye, A. (2009). 'Theorising corporate social responsibility as an essentially contested concept: is a definition necessary?' Journal of Business Ethics, 89 (4): 613-27.

Perrini, F., Russo, A., Tencati, A. and Vurro, C. (2011). 'Deconstructing the relationship between corporate social and financial performance'. Journal of Business Ethics, 102: 59-76.

Porter, M. E. and Kramer, M. R. (2011). 'Creating shared value'. Harvard Business Review, 89 (1-2): 62-77.

Preuss, L. (2008). 'A reluctant stakeholder? On the perception of corporate social responsibility among European trade unions'. Business Ethics: A European Review, 17 (2): $149-60$.

Rathert, N. (2016). 'Strategies of legitimation: MNEs and the adoption of CSR in response to host-country institutions'. Journal of International Business Studies, 47 (7): 858-79.

Riisgaard, L. and Hammer, N. (2011). 'Prospects for labour in global value chains: labour standards in the cut flower and banana industries'. British Journal of Industrial Relations, 49 (1): 168-90.

Seitanidi, M. M. and Crane, A. (2009). 'Implementing CSR through partnerships: understanding the selection, design and institutionalisation of nonprofit-business partnerships'. Journal of Business Ethics, 85: 413-29.

Smyth, R., Qian, X., Nielsen, I. and Kaempfer, I. (2013). 'Working hours in supply chain Chinese and Thai factories: evidence from the Fair Labor Association's "soccer project"”. British Journal of Industrial Relations, 51 (2): 382-408.

Sobczak, A. and Havard, C. (2015). 'Stakeholders' influence on French unions' CSR strategies'. Journal of Business Ethics, 129 (2): 311-24.

Taneja, S., Taneja, P. and Gupta, R. (2011). 'Researches in corporate social responsibility: a review of shifting focus, paradigms, and methodologies'. Journal of Business Ethics, 101 (3): 343-64.

Tang, Z., Hull, C. E. and Rothenberg, S. (2012). 'How corporate social responsibility engagement strategy moderates the CSR-financial performance relationship'. Journal of Management Studies, 49 (7): 1274-303.

Tapia, M., Ibsen, C. L. and Kochan, T. A. (2015). 'Mapping the frontier of theory in industrial relations: the contested role of worker representation'. Socio-Economic Review, 13 (1): 157-84.

Vogel, D. (2006). The Market for Virtue: The Potential and Limits of Corporate Social Responsibility. Washington, DC: The Brookings Institution.

Williams, G., Davies, S. and Chinguno, C. (2015). 'Subcontracting and labour standards: reassessing the potential of international framework agreements'. British Journal of Industrial Relations, 53 (2): 181-203. 